\title{
Historical and simulated ecosystem carbon dynamics in Ghana: land use, management, and climate
}

\author{
Z. Tan ${ }^{1}$, L. L. Tieszen ${ }^{2}$, E. Tachie-Obeng ${ }^{3}$, S. Liu ${ }^{2,4}$, and A. M. Dieye ${ }^{4}$ \\ ${ }^{1}$ SAIC and ARTS, contractors to USGS Earth Resources Observation and Science Center, Sioux Falls, SD 57 198, USA \\ ${ }^{2}$ USGS Earth Resources Observation and Science Center, Sioux Falls, SD 57 198, USA \\ ${ }^{3}$ Ghana Environmental Protection Agency, Accra, Ghana \\ ${ }^{4}$ Geographic Information Science Center of Excellence, South Dakota State University, Brookings, SD 57 007, USA
}

Received: 22 April 2008 - Published in Biogeosciences Discuss.: 2 June 2008

Revised: 25 November 2008 - Accepted: 27 November 2008 - Published: 8 January 2009

\begin{abstract}
We used the General Ensemble biogeochemical Modeling System (GEMS) to simulate responses of natural and managed ecosystems to changes in land use and land cover, management, and climate for a forest/savanna transitional zone in central Ghana. Model results show that deforestation for crop production during the 20th century resulted in a substantial reduction in ecosystem carbon (C) stock from $135.4 \mathrm{MgCha}^{-1}$ in 1900 to $77.0 \mathrm{MgCha}^{-1}$ in 2000 , and in soil organic $C$ stock within the top $20 \mathrm{~cm}$ of soil from $26.6 \mathrm{MgCha}^{-1}$ to $21.2 \mathrm{MgCha}^{-1}$. If no land use change takes place from 2000 through 2100 , low and high climate change scenarios (increase in temperature and decrease in precipitation over time) will result in losses of soil organic C stock by $16 \%$ and $20 \%$, respectively. A low nitrogen $(\mathrm{N})$ fertilization rate is the principal constraint on current crop production. An increase in $\mathrm{N}$ fertilization under the low climate change scenario would lead to an increase in the average crop yield by $21 \%$ with $30 \mathrm{~kg} \mathrm{Nha}^{-1}$ and by $42 \%$ with $60 \mathrm{~kg} \mathrm{~N} \mathrm{ha}^{-1}$ (varying with crop species), accordingly, the average soil $\mathrm{C}$ stock would decrease by $2 \%$ and increase by $17 \%$, in all cropping systems by 2100 . The results suggest that a reasonable $\mathrm{N}$ fertilization rate is critical to achieve food security and agricultural sustainability in the study area through the 21st century. Adaptation strategies for climate change in this study area require national plans to support policies and practices that provide adequate $\mathrm{N}$ fertilizers to sustain soil $\mathrm{C}$ and crop yields and to consider high temperature tolerant crop species if these temperature projections are exceeded.
\end{abstract}

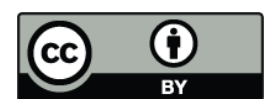

Correspondence to: Z. Tan (ztan@usgs.gov)

\section{Introduction}

Tropical terrestrial ecosystems across the African continent may play an increasing role in the global carbon (C) cycle with potentially significant climate change implications (Stephens et al., 2007), especially in sub-Saharan Africa where the role of land use change in controlling $\mathrm{CO}_{2}$ emissions and annual $\mathrm{C}$ budgets at regional and global scale may be more critical than in other regions (Houghton and Hackler, 2006). Previous studies on the African continent $C$ budget focused only on either forests or conversion of forest to cropland (Houghton and Hackler, 2001, 2006). In fact, human activities such as cutting, fuelwood harvest, fertilization, and other factors affecting net primary productivity also play a critical role in regional and global $\mathrm{C}$ budgets (Nemani et al., 2003; Sankaran et al., 2005; Reich et al., 2006).

With a special emphasis on the fusion of land use change and land management data into model simulations, Liu et al. (2004a) used the General Ensemble biogeochemical Modeling System (GEMS) (Liu et al., 2004b) to simulate C dynamics in vegetation and soil in south-central Senegal from 1900 to 2100 . They observed a decreasing trend in ecosystem $\mathrm{C}$ stock during the 20th century due mainly to deforestation, and predicted that such trends could continue throughout the 21 st century and threaten food security and efficiency of $\mathrm{C}$ sequestration projects. Houghton and Hackler (2006) used a bookkeeping model to estimate the annual $\mathrm{C}$ flux associated with historical changes in land use at a country scale across sub-Saharan Africa and suggested that the annual net $\mathrm{C}$ flux from changes in land use during the 20th century increased quickly and the total source was equivalent to about $15 \%$ of the global net $\mathrm{C}$ flux from land use change in the 1990s. By combining data from regional and global inventories with the forward and inverse model

Published by Copernicus Publications on behalf of the European Geosciences Union. 
analyses, Williams et al. (2007) evaluated C dynamics across the African continent and suggested that Africa is a major source of interannual variability in global atmospheric $\mathrm{CO}_{2}$. Freitag et al. (2008) used an isotope mass balance approach to estimate the annual photosynthetic $\mathrm{C}$ flux over the woodland and savanna-dominated ecosystems of the Volta River basin in West Africa and found that the watershed was a modest source of $\mathrm{CO}_{2}$ to the atmosphere because the estimates of heterotrophic soil respiration exceeded the NPP (net primary production) estimates. On the other hand, with a progressive climate change, low soil nitrogen $(\mathrm{N})$ supply is widely thought to be a major limitation to the response of biomass accumulation to climate warming in the future, even though an elevated atmospheric $\mathrm{CO}_{2}$ generally enhances the photosynthesis (Nemani et al., 2003; Reich et al., 2006), at least in $\mathrm{C}_{3}$ plants.

Ghana is an agriculture-oriented country of sub-Saharan Africa where there has been a nutrient depletion of soil N, phosphorous, and potassium at $20-40 \mathrm{~kg} \mathrm{ha}^{-1} \mathrm{yr}^{-1}$ since the 1950s (Lal, 2007). Low nutrient input, especially low $\mathrm{N}$ fertilizer use rate, has become one of major constraints to crop production and jeopardize the food security (Kelly, 2006). The recent successful increases in maize yields in Malawi have attested to the importance of adequate financial support for fertilizers (http://www.dfid.gov.uk/casestudies/files/ africa/malawi-harvest.asp). Because of the wide range of climates in sub-Sahara Africa, the various crops and managements, and the need for increased food production, a detailed modeling assessment of fertilization needs for specific soils and climates is warranted. In this study we selected the Ejura-Sekyedumasi district of Ghana as a study area because it is a representative forest/savanna transitional zone. We hypothesize that the changes in land use and land cover (LULC) primarily resulted in $\mathrm{C}$ sources at regional or national scales in Ghana during the 20th century. We also propose that the interannual variations of climate and the low rates of $\mathrm{N}$ fertilization will be major forces driving terrestrial ecosystem $\mathrm{C}$ dynamics and fluctuation of crop yields in the future. The objectives of this study were to (1) evaluate the spatial and temporal variations in ecosystem $\mathrm{C}$ stock at a regional scale in the 20th century and (2) simulate the sensitivity of ecosystem $\mathrm{C}$ stock and crop production to changes in $\mathrm{N}$ fertilization with projected warming-drying scenarios through the 21 st century. This study was designed to support the strategies for the development of sustainable agricultural practices to meet food security that was identified by New Partnership for African Development (NEPAD) and has resulted in the implementation of the Comprehensive African Agricultural Development Program (CAADP) and implementation plans at the Africa Fertilizer Summit (http://www.maep.gov.mg/eg/africafertilizer.htm).

\section{Materials and methods}

\subsection{Study area}

The Ejura-Sekyedumasi district in central Ghana (longitudes $1^{\circ} 15^{\prime}-1^{\circ} 40^{\prime} \mathrm{W}$ and latitudes $7^{\circ} 12^{\prime}-7^{\circ} 35^{\prime} \mathrm{N}$ ) covers an area of $1244 \mathrm{~km}^{2}$. It represents the transitional zone from the moist forest in the south to savannas in the north of Ghana. The mean annual minimum and maximum temperatures between 1971 and 2000 were $21.4^{\circ} \mathrm{C}( \pm 0.4)$ and $31.2^{\circ} \mathrm{C}(7 \pm 0.5)$, respectively. The mean annual precipitation was $1226 \mathrm{~mm}( \pm 185)$. The period from April through October had $80 \%$ of the annual precipitation and is defined as the wet season (corresponding to the growing season), and the period from November through March is defined as the dry season in this study. The natural land cover in 1900 was supposed to consist of semideciduous forest and closed savanna woodland (Fig. 1). LULC in the 20th century was dominated by several kinds of cultivated savannas (or agricultural lands) that were derived from semideciduous forest and closed savanna woodland. Major crops include cassava (Manihot esculenta), cocoyam (Xanthosoma tannia), and maize (Zea mays $\mathrm{L}$ ).

\subsection{Modeling system and simulations}

\subsubsection{GEMS (General Ensemble biogeochemical Modeling System)}

The modeling approach (GEMS) applied in Senegal by Liu et al. (2004a) was used in this study to help develop an understanding of the climate and management controls in the more humid country of Ghana and to compare the responses along the gradient from forests to savanna with an analysis of the transition zone. We believed that the model structure and performance of GEMS with results validated in Senegal could provide a solid basis for application in Ghana.

As Liu et al. (2004a) described, GEMS (Liu et al., 2004b) was developed for a better integration of well-established ecosystem models with various spatial databases for simulating biogeochemical cycles over large areas. It has been successfully used to simulate $\mathrm{C}$ dynamics in vegetation and soil at various spatial scales. The CENTURY model (Parton et al., 1994) was selected as the underlying ecosystem biogeochemical model in GEMS because it has solid modules for simulating $\mathrm{C}$ dynamics at the ecosystem level and has been widely applied to various ecosystems worldwide. More detail about GEMS can be referred to Liu et al. (2004b).

Similar to the model application in Senegal by Liu et al. (2004a), modeling architecture in this study was designed for three scenarios: initial C status around 1900, impacts of human disturbances on $\mathrm{C}$ dynamics from 1900 to 2000, and $\mathrm{C}$ trends under a changing climate from 2000 to 2100 . For initial C status around 1900, it was assumed that the ecosystem C flux and soil organic C (SOC) stock in 1900 were 


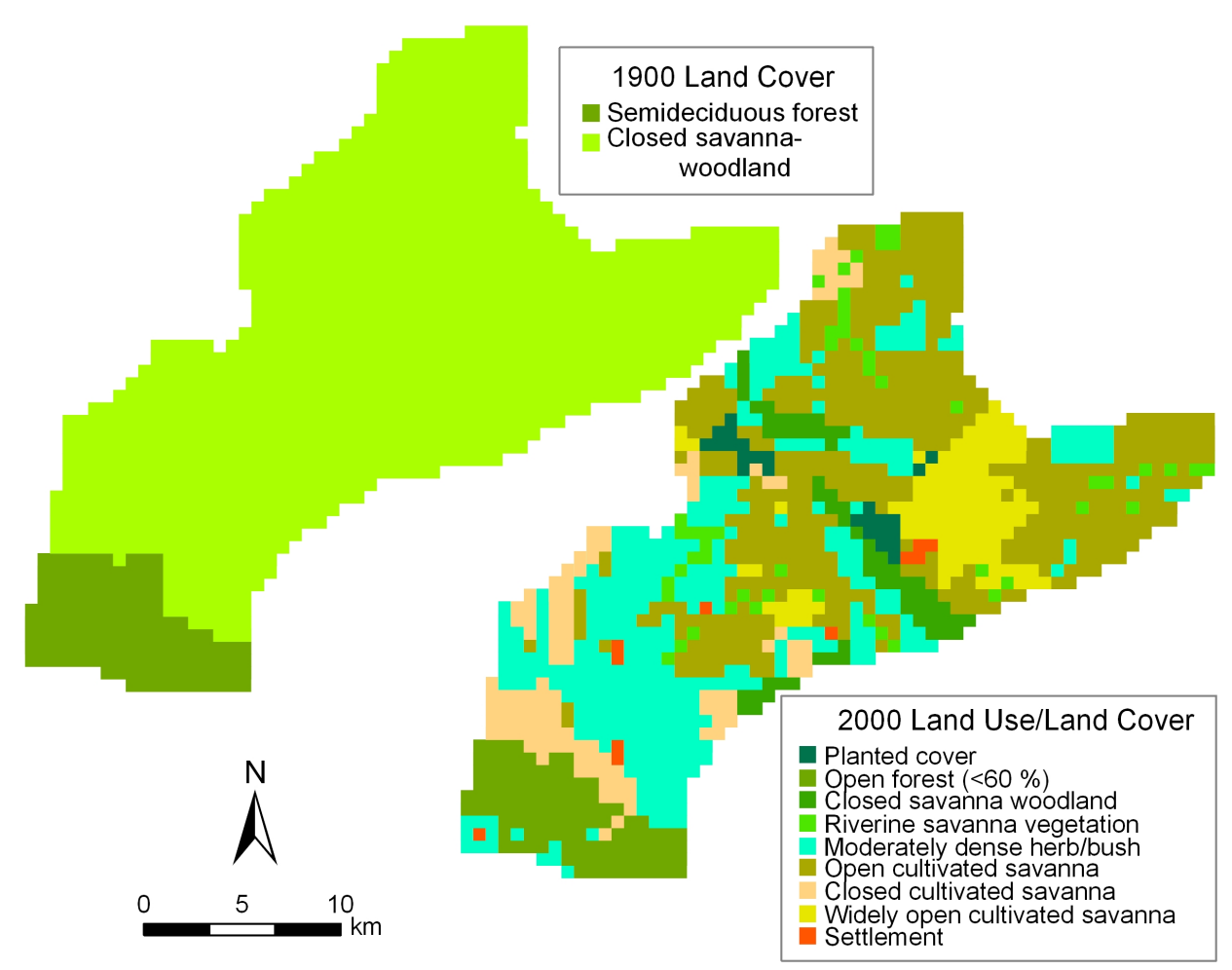

Fig. 1. Land cover types in 1900 (upper left) and land use and land cover types in 2000 (lower right) across the Ejura-Sekyedumasi district in central Ghana.

in equilibrium under natural vegetation, even though human presence could be traced back prior to 1900. Estimates of ecosystem C flux and SOC stock in 1900 were obtained by running GEMS for 1500 years under natural vegetation, climate information from 1971 to 2000, and contemporary soil and drainage conditions.

\subsubsection{Geospatial data for model simulations}

The spatial simulation unit of GEMS is a JFD (joint frequency distribution) case. A JFD case (i.e. a grid) contains multiple, homogeneous, connected or isolated land pixels that represent a unique combination of values from the Geographic Information System (GIS) layers. The GIS layers for JFD generation in this study consisted of mean monthly precipitation, mean monthly minimum and maximum temperatures, historical LULC change dynamic data that were derived from three time series of Landsat images (1972, 1986, and 2000) provided by Ghana Environmental Protection Agency and Center for Remote Sensing and Geographical Information System (CERSGIS), soil inventory taken from the FAO soil database. A total of 164 JFD cases with a pixel size of $1 \mathrm{~km}$ by $1 \mathrm{~km}$ were resulted from the combination of these GIS layers in this study.

\subsubsection{Management practice data}

The information of management practices for this study was synthesized from sample site investigations across the study area and literature. The dataset of management practices for model simulations consisted of crop composition, crop rotation, fallow, and harvesting options (or residue management). These kinds of information and their parameters used in GEMS are listed in Table 1. As well as crop residues retained in field (see Table 1D), manure addition to cropped field has been thought a major nutrient source for crops and the amount of an average level of $2.0 \mathrm{Mg} \mathrm{ha}^{-1}$ was considered for modeling. Both hand- and animal-driven plowing methods were applied for tillage. The frequency of fuelwood production from woodlands was assumed to be one time each year. GEMS automates the processes of downscaling those data for $\mathrm{C}$ budget simulations.

\subsubsection{Ensemble simulations and uncertainty control}

According to Liu et al. (2004b), GEMS generates site-level inputs with a Monte Carlo approach from regional datasets. Because any single simulation of a JFD case is a unique combination of the spatial units in common of all input GIS layers, the output of a single simulation run of a JFD might be biased. Therefore, ensemble simulations of each JFD are 
Table 1. Parameters of management practices used in model simulations.

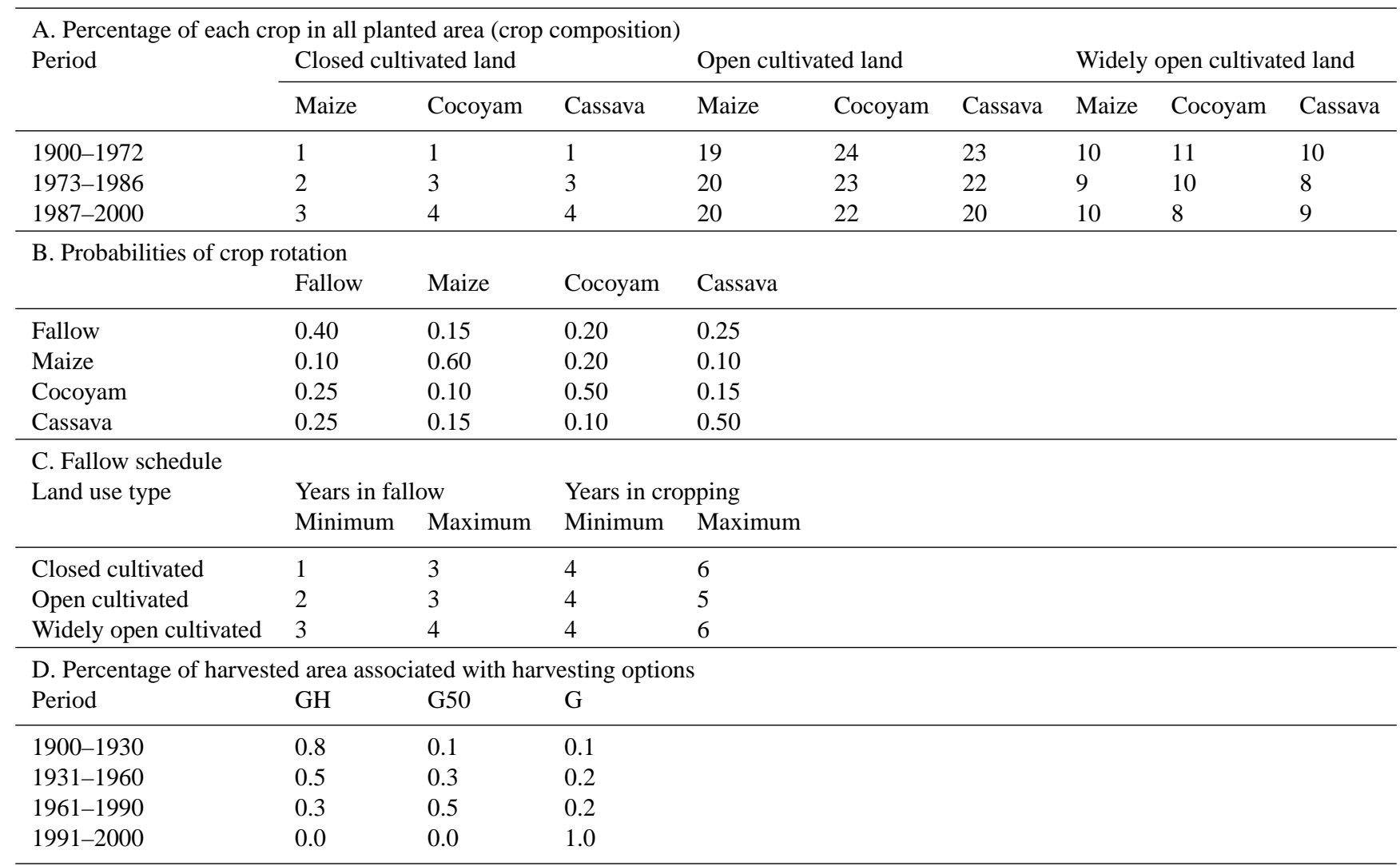

Note: GH, harvesting all grain and stalk; G50, harvesting grain and 50\% of stalk; G, harvesting grain only.

executed to incorporate the variability of inputs. In general, the outputs of ensemble simulations become more stable when increasing the number of simulation runs (Liu et al., 2004b). We made 20 repeat runs for each JFD case in this study to insure stable outputs. Values of selected output variables were written to a set of output files after each model execution and then aggregated for the study area using SAS Macros programming. Meanwhile, the uncertainty of simulations was evaluated in terms of the coefficient of variation $(\mathrm{CV})$ with all model outputs. More importantly, we used the field observation data of the ecosystem $\mathrm{C}$ and SOC stocks and the grain yields of major crops as references to verify the corresponding outputs, and repeatedly ran model simulations by adjusting parameters after each run until the outputs matched the field measurements as closely as possible. Therefore, the model outputs should represent the general patterns of $\mathrm{C}$ dynamics across the study area.

\subsection{Simulation scenarios}

\subsubsection{Scenarios for the 20th century}

Based on the initial C status around 1900 by running the GEMS under the natural vegetation condition, we ran GEMS using the input data as described above and management data (see Table 1). The average $\mathrm{N}$ fertilizer application rate of $4 \mathrm{~kg} \mathrm{Nha}^{-1} \mathrm{yr}^{-1}$ across the country from 1970 to 2000 (http://earthtrends.wri.org/) and conventional tillage practice were assumed to remain through the 20th century.

\subsubsection{Climate change scenarios for the 21 st century}

Following the IPCC Special Report on Emissions Scenarios (SRES), Hulme et al. (2001) integrated a new observed global climate data into several Global Climate Models, coupled with the Model for the Assessment of Greenhouse Induced Climate Change (MAGICC) (Wigley et al., 2000), and developed an approach to evaluate the changes in both continental and regional seasonal-mean temperature and rainfall across the African continent. The approach of Hulme et al. (2001) was successfully used by Liu et al. (2004a) to set climate change scenarios for their study area in Senegal. 
The Africa focus of Hulme's approach and its compliance with the IPCC SRES emissions scenarios made us believe that the simulation results under the climate change scenarios formulated by this approach should be comparable to those estimated from the approaches recommended in the IPCC Fourth Assessment Report (http://www.ipcc.ch/ipccreports/ ar4-syr.htm). In order to evaluate the impacts of future climate change on ecosystem $\mathrm{C}$ dynamics during the 21 st century, the approach of Hulme et al. (2001) was used to set three climate change scenarios for our study area.

1. No Climate Change (NCC): the average monthly values of precipitation and mean monthly minimum and maximum temperatures from 1971 to 2000 are supposed to stay for the 21 st century.

2. Low Climate Change (LCC): the projected minimum changes in annual precipitation and minimum and maximum temperatures by 2100 are proportionally allocated to each month based on the average monthly values from 1971 to 2000 (i.e. baselines). Under this scenario, the annual precipitation will decrease by $110 \mathrm{~mm}$ in 2100 , and the minimum and maximum temperatures will increase by $2.7^{\circ} \mathrm{C}$ and $2.2^{\circ} \mathrm{C}$, respectively.

3. High Climate Change (HCC): similar to LCC, under this scenario, the annual precipitation will have a reduction of $234 \mathrm{~mm}$ by 2100 , and the mean monthly minimum and maximum temperatures will increase by $4.3^{\circ} \mathrm{C}$ and $3.4^{\circ} \mathrm{C}$, respectively.

\subsubsection{Nitrogen fertilization rates for the 21 st century}

Besides manure, $\mathrm{N}$ fertilizers are the dominant $\mathrm{N}$ source applied to crops in Ghana. The average $\mathrm{N}$ fertilizer application rate across the country from 1970 to 2000 was only about $4 \mathrm{~kg} \mathrm{Nha}^{-1} \mathrm{yr}^{-1}$ (http://earthtrends.wri.org/). According to the Crop Services Department of Ministry of Food and Agriculture of Ghana, the levels of fertilizers applied for maize production are recommended as: $120 \mathrm{~kg} \mathrm{ha}^{-1}$ of compound fertilizer (consisting of nitrogen, phosphorus, and potassium) applied during planting, $120 \mathrm{~kg} \mathrm{ha}^{-1}$ of ammonium sulfate $\left(\left(\mathrm{NH}_{4}\right)_{2} \mathrm{SO}_{4}\right)$ for top dressing, and another $120 \mathrm{~kg} \mathrm{ha}^{-1}$ of ammonium sulfate applied during tussling stage (Communication with Tachie-Obeng, EPA of Ghana). The annual total fertilization rate recommended for maize production is about $60 \mathrm{~kg} \mathrm{~N} \mathrm{ha}^{-1} \mathrm{yr}^{-1}$. Liu et al. (2004a) documented that the $\mathrm{N}$ fertilization rate of $30 \mathrm{~kg} \mathrm{Nha}^{-1} \mathrm{yr}^{-1}$ is usually applied on intensive and extensive croplands in south-central Senegal. Therefore, we set three $\mathrm{N}$ fertilization scenarios for all crops through the 21st century as follows:

(1) $\mathrm{N} 4$, the average $\mathrm{N}$ fertilizer application rate of $4 \mathrm{~kg} \mathrm{Nha}^{-1} \mathrm{yr}^{-1}$ is supposed to continue through the 21 st century,

(2) $\mathrm{N} 30$, the $\mathrm{N}$ fertilization rate increases to $30 \mathrm{~kg} \mathrm{~N} \mathrm{ha}^{-1} \mathrm{yr}^{-1}$ after 2000, and
(3) $\mathrm{N} 60$, the $\mathrm{N}$ fertilization rate increases to $60 \mathrm{~kg} \mathrm{~N} \mathrm{ha}^{-1} \mathrm{yr}^{-1}$ after 2000.

Model simulations for each scenario addressed above were made with an assumption that there are no changes in LULC and other management practices.

\section{Results and discussion}

\subsection{Changes in land use and land cover}

The LULC types and their changes across the district are presented in Table 2. Assuming all land was covered by natural semideciduous forest (10.5\%) and closed savanna woodland $(89.5 \%)$ before 1900 , by the year 2000 these classes accounted for only $4.1 \%$ and $2.5 \%$ of the land area, respectively, due to the cultivation for crop production and the change or degradation to savannas as listed in Table 2. As a result, the cultivated savanna lands (including closed-, open-, and widely open cultivated savanna classes) have become a predominant LULC type, occupying $70.4 \%$ of all land. About $13.5 \%$ of the total land area was directly involved in LULC change between 1972 and 2000, with major conversions from open forest and closed savanna woodland to openand closed cultivated savannas.

\subsection{Carbon dynamics in the 20th century}

At the regional scale, there was a significant reduction in ecosystem $\mathrm{C}$ stock (i.e. the sum of live and dead aboveground and belowground biomass $\mathrm{C}$ and SOC in the top $20 \mathrm{~cm}$ soil) during the 20th century, from $135.4 \mathrm{Mg} \mathrm{Cha}^{-1}$ in 1900 to $77 \mathrm{MgC} \mathrm{ha}^{-1}$ in 2000 . The spatial and temporal trends for four selected years are illustrated in Fig. 2. A similar change trend was observed across south-central Senegal in the 20th century by Liu et al. (2004a) using the same simulation approach. Such a reduction could be mainly attributed to the substantial removal of aboveground biomass by deforestation for agricultural use. For example, the living biomass was reduced from $100 \mathrm{MgC} \mathrm{ha}^{-1}$ in 1900 to $52.4 \mathrm{MgC} \mathrm{ha}^{-1}$ in 2000 , accounting for $80 \%$ of the total reduction in ecosystem C stock, which is comparable to the contribution (88\%) estimated by Liu et al. (2004a) for south-central Senegal. Meanwhile, the total SOC stock decreased from $26.6 \mathrm{Mg} \mathrm{Cha}^{-1}$ in 1900 to $21.2 \mathrm{MgC} \mathrm{ha}^{-1}$ in 2000 , representing a reduction of about $21 \%$. This kind of SOC loss was dominantly related to cultivation-enhanced emissions after deforestation (Houghton, 1995, 2003; Guo and Gifford, 2002; Liu et al., 2004) because the interpretation of time-series Landsat images from 1972 to 2000 indicates that the area of all cultivated savanna lands was increased by $95 \mathrm{~km}^{2}$ which happened to be equivalent to the reduced area of the forest and close savanna woodland during the same period (Table 2). 


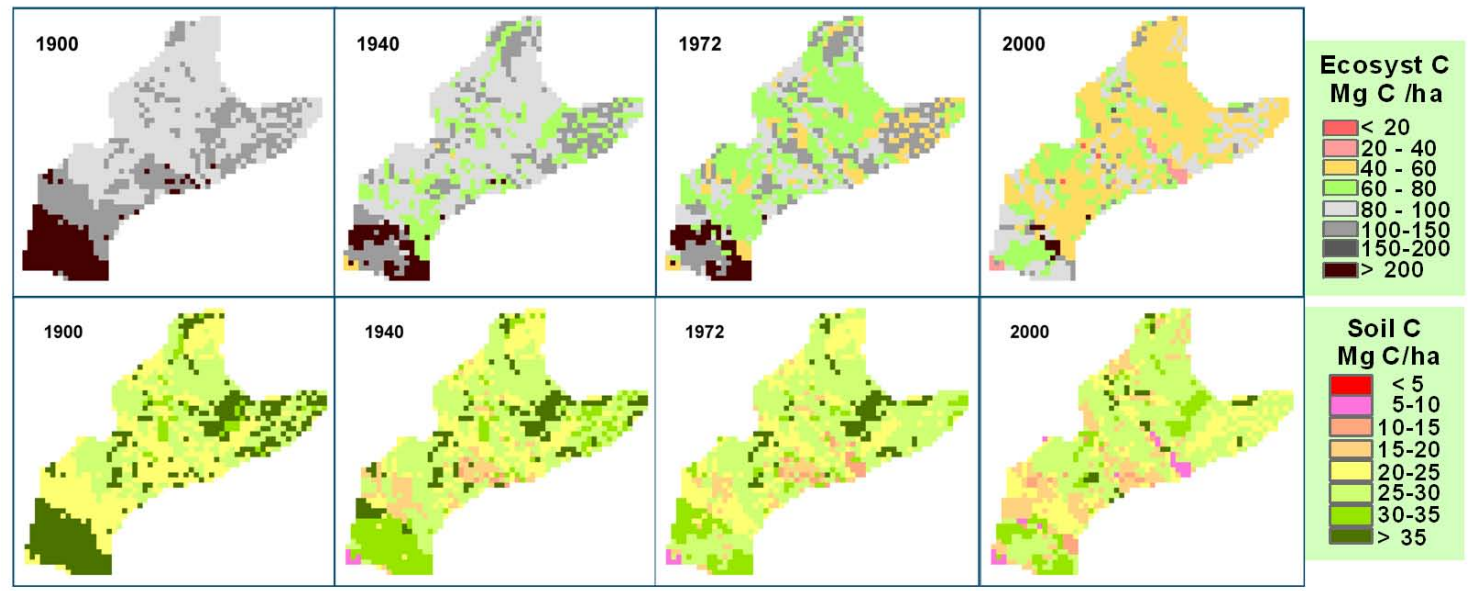

Fig. 2. Spatiotemporal trends of ecosystem $C$ and soil organic $C$ stocks across the Ejura-Sekyedumasi district for the selected years during the 20th century.

Table 2. Land use and land cover type, area, and change rate across the Ejura-Sekyedumasi district from 1972 to 2000.

\begin{tabular}{lllllllll}
\hline Land use and land cover type & 1900 & 1972 & 2000 & Change by 2000 & \multicolumn{2}{c}{ Change $^{\mathrm{b}}$} & & \\
\cline { 2 - 9 } & $\mathrm{km}^{2}$ & $\%$ & $\mathrm{~km}^{2}$ & $\%^{\mathrm{a}}$ & $\mathrm{km}^{2}$ & $\%^{\mathrm{a}}$ & $\mathrm{km}^{2}$ & $\% / \mathrm{yr}$ \\
\hline Semideciduous forest & 130 & 10.5 & & & & & & \\
Closed savanna woodland & 1114 & 89.5 & 71 & 5.7 & 31 & 2.5 & -40 & -0.11 \\
Open forest (<60\%) & & & 106 & 8.5 & 51 & 4.1 & -55 & -0.16 \\
Riverine savanna vegetation & & & 82 & 6.6 & 42 & 3.4 & -40 & -0.11 \\
Plantation cover & & & 27 & 2.2 & 49 & 3.9 & 22 & 0.06 \\
Moderately dense herb/bush & & & 207 & 16.6 & 220 & 17.7 & 13 & 0.04 \\
Closed cultivated savanna & & & 50 & 4.0 & 100 & 8.0 & 50 & 0.14 \\
Open cultivated savanna & & & 463 & 37.2 & 541 & 43.5 & 78 & 0.22 \\
Widely open cultivated savanna & & & 226 & 18.2 & 193 & 15.5 & -33 & -0.09 \\
Settlement & & & 12 & 1.0 & 17 & 1.4 & 5 & 0.01 \\
Total & \multirow{2}{*}{1244} & 100 & 1244 & 100 & 1244 & 100 & 168 & 0.48 \\
\hline
\end{tabular}

${ }^{a}$ Pecentage of the total land area. ${ }^{b}$ Mean annual change percentage of the total land area between 1972 to 2000.

However, the dynamics of SOC and the magnitude of SOC loss varied significantly with LULC types (see Fig. 3). Open forest demonstrated a remarkable declining trend in SOC content over the 20th century (mainly in the first 40 years). The $\mathrm{C}$ density in $\mathrm{MgCha}^{-1}$ is the average of the land cover class at any given time. Any change shown in Fig. 3 represents the overall average change in SOC density for that class. SOC changes shown here could be attributed to two major reasons: (1) degradation of natural forests to open forest and degradation of open forest itself owning to wildfires, charcoal production, and traditional slash (Allotey and Tachie-Obeng, 2006), and (2) deforestation for cultivation started preferably from sites with high soil organic matter content, while the soils with higher SOC stocks more easily lose SOC following cultivation (Tan et al., 2006a, b). Very small reduction was simulated for savanna woodland and riverine savanna. On the contrary, the dynamics of SOC showed noticeable interannual variations across the herb/bush savanna and all cultivated savannas, especially during the period prior to 1970 . We attribute these variations to the following reasons. First, in the absence of documented LULC data prior to 1972, the changes from either the native savanna, savanna woodland or the natural forests to any other land uses before 1972 were randomly determined by GEMS, while the initial SOC stock levels differed considerably between the savanna woodland and the natural forests. Second, extensive cultivation and traditional burn farming methods (Allotey and Tachie-Obeng, 2006) could enhance 


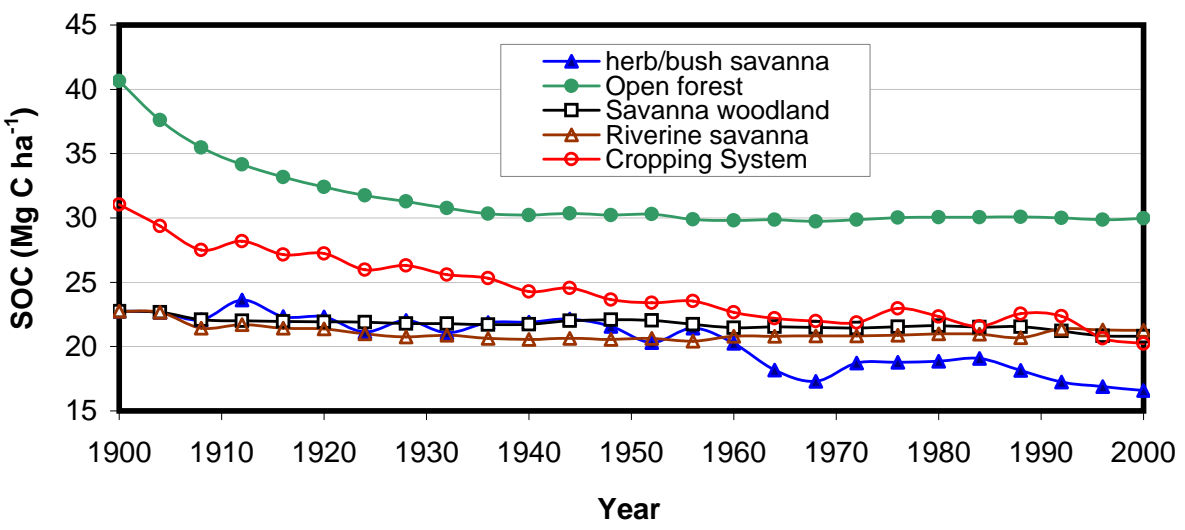

Fig. 3. Soil organic carbon (SOC) dynamic trends through the 20th century simulated for major land use and land cover types in the EjuraSekyedumasi district (Note: The SOC stock value for each LULC type was simulated only for what the land was. In fact, the area of each LULC type used for C calculation at any time point is variable, which, however, was supposed to have little influence on the general dynamic trends. The SOC value for cropland in 1900 when no cropland was assumed represents the average initial SOC level of the forestland which was converted to cropland after 1900).

decomposition of soil organic matter and consequently result in a significant SOC loss. Third, variations in cropping system (or crop rotation) and management practices might play an important role in the SOC loss from all cultivated savannas. For example, because of differences in biomass production among cocoyam, cassava, and maize cropping systems, any changes in cropping systems could greatly contribute to the variation in SOC stock at an annual time scale. Averaging for all cropping systems, there was a reduction of $35 \%$ SOC by the year 2000. This SOC reduction rate is about $8 \%$ higher than that reported by Liu et al. (2004a) for southcentral Senegal but much lower than the rate $(50 \%$ for the top $10 \mathrm{~cm}$ rather than top $20 \mathrm{~cm}$ depth of soil) of Aweto and Obe (1993) obtained from the Idi-Ayunre/Omi-Adio of Nigeria. In comparison to our study area, the forested land in the Idi-Ayunre/Omi-Adio has a higher SOC stock (especially in the top soil) because of higher precipitation, while the higher $\mathrm{C}$ emission rate likely occurs in soils with higher baseline SOC stocks after conversion for crop production (Tan et al., 2006a, b).

\subsection{Ecosystem $\mathrm{C}$ budgets associated with projected climate change scenarios}

We did simulations for each projected climate change scenario with an assumption that there are no changes in LULC and land management and that the fertilization rate of $4 \mathrm{~kg} \mathrm{Nha}^{-1}$ remains for croplands through the 21 st century, and the results are presented in Table 3. Generally, by the year 2100, the whole study area will become a small $\mathrm{C}$ source. However, the ecosystem $\mathrm{C}$ budgets over either the whole area or individual LULC sectors would heavily count on their SOC balances. As indicated by the data in Table 3 , the SOC stock across the study area will reduce by $6 \%$,
$16 \%$, and $20 \%$ under NCC, LCC, and HCC, respectively. C sources could happen to all kinds of LULC ecosystems but be dominantly contributed by the SOC loss from cultivated savannas and moderately dense herb/bush savanna. Compared with the NCC scenario, both LCC and HCC scenarios were simulated to lead to a significant reduction in the mean SOC stock, but no significant difference was tested between LCC and HCC (see Table 3). Note from Table 3 that SOC (particularly in the cultivated savannas and herb/bush savanna) is more sensitive to the climate change than is aboveground biomass production. On the other hand, the SOC change (decrease) rates in almost all LULC types (except plantation, which is not listed in Table 3) were tested to be significant $(p<0.01)$, especially under LCC and HCC. As addressed in the previous section, this SOC loss can be attributed to the tillage practices and higher $\mathrm{C}$ decomposition rate triggered by higher temperature. The spatiotemporal patterns of both ecosystem $\mathrm{C}$ and SOC budgets under the HCC for selected years are illustrated in Fig. 4.

\subsection{Responses of crop grain yields to $\mathrm{N}$ fertilization}

Our simulations focused on three major crops: cassava, cocoyam, and maize. As shown in Table 4, crop grain yields over the 21st century will depend significantly upon the application rate of $\mathrm{N}$ fertilizers. Compared with N4, N30 and N60 will lead to a significant increase in grain yields of all three crops. T test also shows a significant difference in mean yields between N30 and N60. Although HCC would lead to some reduction in yields in comparison to either NCC or LCC, no significant differences in crop yields are tested between any two climate change scenarios. The responses of crop yield to $\mathrm{N}$ fertilization vary with crop species. Under all climate change scenarios, N60 could lead to the greatest 

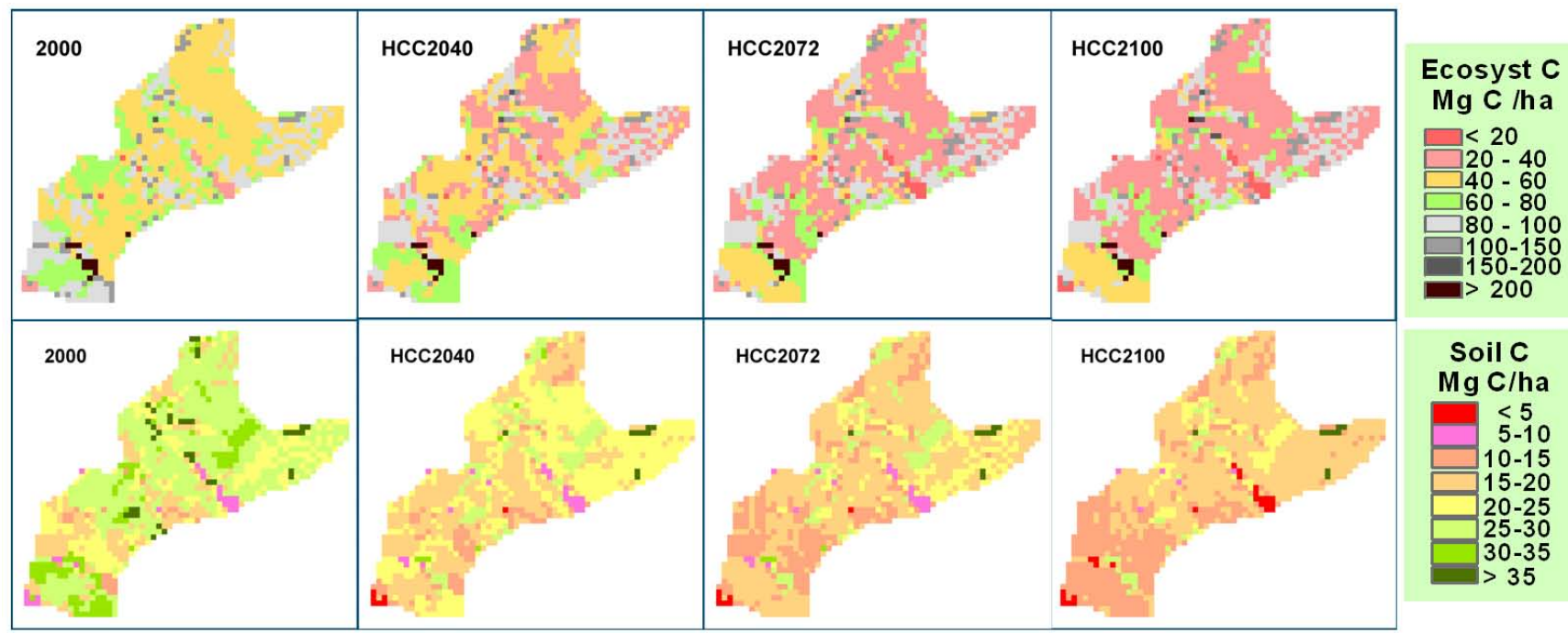

Fig. 4. Spatial patterns of ecosystem C and SOC stocks under high climate change scenario (HCC) in the Ejura-Sekyedumasi district for the selected years during the 21 st century.

increase in cocoyam yield, followed by maize. The dynamic trends of all three crop yields through the 21st century indicate that existing $\mathrm{N}$ fertilization level (N4) will not sustain crop production, suggesting an increasing dependency of crop yields on fertilizers under a changing climate, especially maize. Existing $\mathrm{N}$ fertilizer input will also result in pronounced interannual variations in yields (see Fig. 5). In other words, crop production with little or lower $\mathrm{N}$ fertilization rates are much less stable and more vulnerable to uncertainties of climate variables, implying that an increase in $\mathrm{N}$ fertilization rate can offset some adverse impacts of progressive climate warming-drying stresses. That may be why the change $(\%)$ in these crop yields with $\mathrm{N} 4$ calculated from the yield differences between 2000 and 2100 are not consistent (see Table 4). Generally the response of crop yield to N60 application rate is cumulative (increase) during the first 30 years and remains consistent for about another 40 years. These results suggest that the response of crop yield to $\mathrm{N}$ fertilization is much stronger than to climate change. This may be dominantly attributed to the low baseline soil $\mathrm{N}$ content because the average total soil $\mathrm{N}$ content for all cropping systems in 2000 was estimated at $1.95 \mathrm{Mg} \mathrm{N} \mathrm{ha}^{-1}$. Even in Latin America and Asia where the fertilization rate is $8-15$ times that in sub-Saharan Africa, the fertilizer use contributes as much as $50 \%$ of the Green Revolution yield growth (Kelly, 2006). Onumah and Coulter (2000) reported that the crop yield in the transitional zone of Ghana rose to $4.8 \mathrm{Mg} \mathrm{ha}^{-1}$ with application of fertilizers but dropped to $1.5-2.0 \mathrm{Mg} \mathrm{ha}^{-1}$ without fertilizers. As recommended by Adiku et al. (1998) for a sustainable production in savanna zones, our results also suggest that a modest $\mathrm{N}$ fertilization rate (for example about $30 \mathrm{~kg} \mathrm{Nha}^{-1} \mathrm{yr}^{-1}$ ) would be neces- sary to ensure food security and healthy cropping ecosystem performance across the Ejura-Sekyedumasi district. Such fertilization level can result in high fertilizer use efficiency even though it is not enough to maximize crop yield due to limits of human capital and financial capability (Kelly, 2006).

\subsection{Dynamics of soil C stock within cropping systems as} related to $\mathrm{N}$ fertilization

The data presented in Table 5 show that increasing $\mathrm{N}$ fertilization rate in all cropping systems can significantly enhance sequestering atmospheric $\mathrm{C}$ into soil, depending on $\mathrm{N}$ fertilization rates and projected climate change scenarios. However, N4 fertilization rate will lead to a significant decrease in SOC stock by $18 \%$ and $23 \%$ under LCC and $\mathrm{HCC}$, respectively, representing soil $\mathrm{C}$ sources at rates of 38 and $49 \mathrm{~kg} \mathrm{Cha}^{-1} \mathrm{yr}^{-1}$, respectively. In our case, the N30 fertilization rate could marginally offset the decomposition of SOC that results from the projected climate change, with a sink of $27 \mathrm{~kg} \mathrm{Cha}^{-1} \mathrm{yr}^{-1}$ under NCC, a $\mathrm{C}$ sink of $5 \mathrm{~kg} \mathrm{Cha}^{-1} \mathrm{yr}^{-1}$ under LCC, and a $\mathrm{C}$ source of $14 \mathrm{~kg} \mathrm{Cha}^{-1} \mathrm{yr}^{-1}$ under HCC. The N60 application rate could help all cropping systems turn out to be a $\mathrm{C}$ sink of $66 \mathrm{~kg} \mathrm{Cha}^{-1} \mathrm{yr}^{-1}$ under NCC, $37 \mathrm{kgCha}^{-1} \mathrm{yr}^{-1}$ under LCC and $32 \mathrm{~kg} \mathrm{Cha}^{-1} \mathrm{yr}^{-1}$ under HCC. The change trends of SOC budgets from 2000 through 2100 are illustrated in Fig. 6. Note from Fig. 6 that the effects of $\mathrm{N}$ fertilizers on maintaining soil fertility at low $\mathrm{N}$ fertilization rates and enhancing SOC sequestration at high $\mathrm{N}$ fertilization rates seem to be cumulative for the first several decades and to deteriorate afterwards. The different projected climate change 

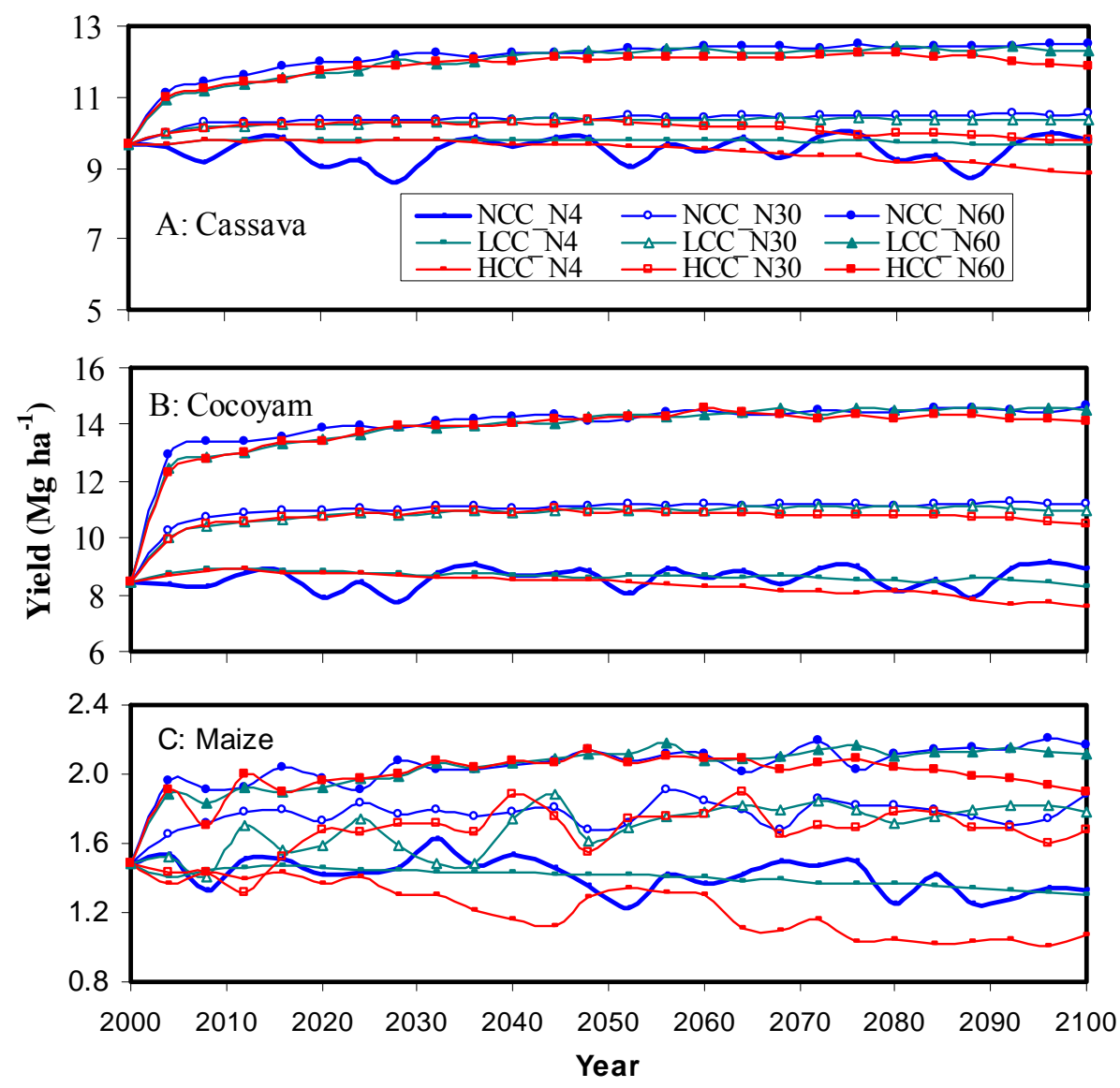

Fig. 5. Simulated responses of crop yield to N fertilization rates under projected climate change scenarios from 2000 to 2100 (NCC, LCC, and $\mathrm{HCC}$ represent no climate change with normal $\mathrm{N}$ fertilization rate, low climate change, and high climate change scenarios, respectively. $\mathrm{N} 4, \mathrm{~N} 30$, and $\mathrm{N} 60$ refer to $\mathrm{N}$ fertilization rates of 4,30 , and $60 \mathrm{~kg} \mathrm{Nha}^{-1} \mathrm{yr}^{-1}$, respectively).

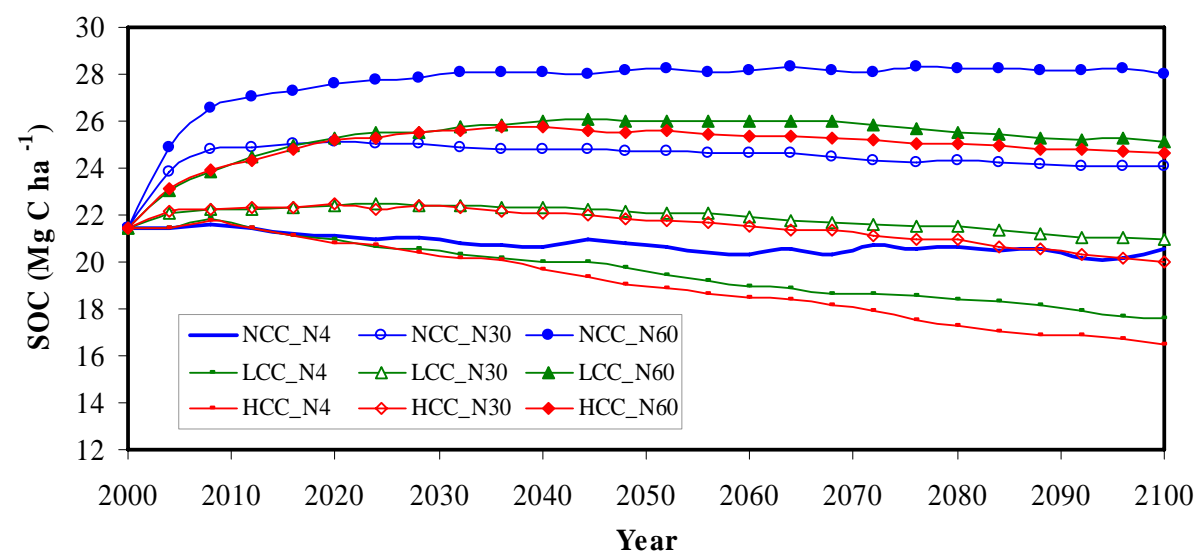

Fig. 6. Simulated responses of soil organic carbon stock (SOC) in cropping systems to $\mathrm{N}$ fertilization rates and climate change scenarios from 2000 to 2100 (NCC, LCC, and HCC represent no climate change, low, and high climate change scenarios, respectively. N4, N30, and N60 refer to $\mathrm{N}$ fertilization rates of 4,30 , and $60 \mathrm{~kg} \mathrm{~N} \mathrm{ha}^{-1} \mathrm{yr}^{-1}$, respectively). 
Table 3. Consequences of projected climate change to ecosystem carbon and soil organic carbon (SOC) stocks at the district scale.

\begin{tabular}{|c|c|c|c|c|c|c|}
\hline \multirow[t]{2}{*}{ Land use } & Climate change scenario & 2000 & 2100 & Mean $^{\mathrm{a}}$ & \multirow[t]{2}{*}{ Stdev } & \multirow{2}{*}{$\begin{array}{l}\text { Change }^{\mathrm{b}} \\
(\%)\end{array}$} \\
\hline & & & \multicolumn{2}{|c|}{$\mathrm{MgCha}^{-1}$} & & \\
\hline \multicolumn{7}{|c|}{ Ecosystem C Stock } \\
\hline All land & $\begin{array}{l}\text { NCC } \\
\text { LCC } \\
\text { HCC }\end{array}$ & $\begin{array}{l}77.0 \\
77.0 \\
77.0\end{array}$ & $\begin{array}{l}74.2 \\
73.0 \\
70.9\end{array}$ & $\begin{array}{l}75.2 \\
74.1 \\
73.4^{*}\end{array}$ & $\begin{array}{l}0.8 \\
0.9 \\
1.5\end{array}$ & $\begin{array}{l}-4 \\
-5 \\
-8\end{array}$ \\
\hline Open forest & $\begin{array}{l}\text { NCC } \\
\text { LCC } \\
\text { HCC }\end{array}$ & $\begin{array}{l}240.3 \\
240.3 \\
240.3\end{array}$ & $\begin{array}{l}241.1 \\
246.5 \\
242.7\end{array}$ & $\begin{array}{l}242.2 \\
242.9 \\
242.0\end{array}$ & $\begin{array}{l}0.8 \\
6.2 \\
2.4\end{array}$ & $\begin{array}{l}0 \\
3 \\
1\end{array}$ \\
\hline $\begin{array}{l}\text { Savanna } \\
\text { woodland }\end{array}$ & $\begin{array}{l}\text { NCC } \\
\text { LCC } \\
\text { HCC }\end{array}$ & $\begin{array}{l}92.6 \\
92.6 \\
92.6\end{array}$ & $\begin{array}{l}94.8 \\
96.4 \\
93.8\end{array}$ & $\begin{array}{l}94.4 \\
94.7 \\
94.1\end{array}$ & $\begin{array}{l}2.2 \\
3.8 \\
1.3\end{array}$ & $\begin{array}{l}2 \\
4 \\
1\end{array}$ \\
\hline $\begin{array}{l}\text { Moderately } \\
\text { dense } \\
\text { herb/bush }\end{array}$ & $\begin{array}{l}\text { NCC } \\
\text { LCC } \\
\text { HCC }\end{array}$ & $\begin{array}{l}72.8 \\
72.8 \\
72.8\end{array}$ & $\begin{array}{l}84.9 \\
84.1 \\
81.2\end{array}$ & $\begin{array}{l}79.9 \\
78.4 \\
77.6^{* *}\end{array}$ & $\begin{array}{l}12.1 \\
11.3 \\
8.4\end{array}$ & $\begin{array}{l}17 \\
16 \\
12\end{array}$ \\
\hline $\begin{array}{l}\text { Cultivated } \\
\text { savannas }\end{array}$ & $\begin{array}{l}\text { NCC } \\
\text { LCC } \\
\text { HCC }\end{array}$ & $\begin{array}{l}46.8 \\
46.8 \\
46.8\end{array}$ & $\begin{array}{l}34.2 \\
30.7 \\
29.6\end{array}$ & $\begin{array}{l}39.4 \\
37.8 \\
37.2^{*}\end{array}$ & $\begin{array}{l}-12.0 \\
-16.0 \\
-17.2\end{array}$ & $\begin{array}{l}-26 \\
-34 \\
-37\end{array}$ \\
\hline Soil C Stock & & & & & & \\
\hline All land & $\begin{array}{l}\text { NCC } \\
\text { LCC } \\
\text { HCC }\end{array}$ & $\begin{array}{l}21.2 \\
21.2 \\
21.2\end{array}$ & $\begin{array}{l}20.0 \\
17.8 \\
16.9\end{array}$ & $\begin{array}{l}20.2 \\
19.2^{*} \\
18.9^{*}\end{array}$ & $\begin{array}{l}0.4 \\
1.0 \\
1.3\end{array}$ & $\begin{array}{l}-6 \\
-16 \\
-20\end{array}$ \\
\hline Open forest & $\begin{array}{l}\text { NCC } \\
\text { LCC } \\
\text { HCC }\end{array}$ & $\begin{array}{l}30.2 \\
30.2 \\
30.2\end{array}$ & $\begin{array}{l}30.9 \\
29.2 \\
28.5\end{array}$ & $\begin{array}{l}30.6 \\
29.5^{* * *} \\
29.3^{* * *}\end{array}$ & $\begin{array}{l}0.7 \\
-1.1 \\
-1.8\end{array}$ & $\begin{array}{l}2 \\
-3 \\
-6\end{array}$ \\
\hline $\begin{array}{l}\text { Savanna } \\
\text { woodland }\end{array}$ & $\begin{array}{l}\text { NCC } \\
\text { LCC } \\
\text { HCC }\end{array}$ & $\begin{array}{l}20.9 \\
20.9 \\
20.9\end{array}$ & $\begin{array}{l}21.2 \\
20.1 \\
19.5\end{array}$ & $\begin{array}{l}21.1 \\
20.5^{* * *} \\
20.3^{* * *}\end{array}$ & $\begin{array}{l}0.3 \\
-0.8 \\
-1.4\end{array}$ & $\begin{array}{l}1 \\
-4 \\
-7\end{array}$ \\
\hline $\begin{array}{l}\text { Moderately } \\
\text { dense } \\
\text { herb/bush }\end{array}$ & $\begin{array}{l}\text { NCC } \\
\text { LCC } \\
\text { HCC }\end{array}$ & $\begin{array}{l}16.2 \\
16.2 \\
16.2\end{array}$ & $\begin{array}{l}14.6 \\
13.5 \\
12.8\end{array}$ & $\begin{array}{l}15.0 \\
14.4^{* * *} \\
14.1^{* * *}\end{array}$ & $\begin{array}{l}-1.6 \\
-2.8 \\
-3.4\end{array}$ & $\begin{array}{l}-10 \\
-17 \\
-21\end{array}$ \\
\hline $\begin{array}{l}\text { Cultivated } \\
\text { savannas }\end{array}$ & $\begin{array}{l}\text { NCC } \\
\text { LCC } \\
\text { HCC }\end{array}$ & $\begin{array}{l}21.4 \\
21.4 \\
21.4\end{array}$ & $\begin{array}{l}20.6 \\
17.6 \\
16.5\end{array}$ & $\begin{array}{l}20.8 \\
19.7^{* * *} \\
19.1^{* * *}\end{array}$ & $\begin{array}{l}-0.9 \\
-3.8 \\
-4.9\end{array}$ & $\begin{array}{l}-4 \\
-18 \\
-23\end{array}$ \\
\hline
\end{tabular}

a Average for the 21st century.

${ }^{b}$ Change percentage of carbon stock by the year 2100 based on that in 2000 .

NCC, LCC, and HCC represent no, low, and high climate change scenarios, respectively.

${ }^{*},{ }^{* *}$, and ${ }^{* * *}$ represent significant difference made in mean C stock by either LCC or HCC from that under NCC at $p<0.1,0.05$, and 0.01 , respectively.

scenarios will result in significant differences in SOC stock with no and very low $\mathrm{N}$ fertilization only. But such differences will become insignificant with increasing $\mathrm{N}$ fertilization rates regardless of climate change scenarios.
The data presented in Figs. 5 and 6 show an interaction between $\mathrm{N}$ and $\mathrm{C}$ elements in biomass and soil organic matter. In fact, the photosynthetic requirement of plants for $\mathrm{N}$, coupled with relatively low levels of available $\mathrm{N}$ in many terrestrial ecosystems, causes $\mathrm{C}$ uptake and storage on land to be tightly regulated by the $\mathrm{N}$ cycle (Vitousek and Howarth, 
Table 4. Crop yields in response to $\mathrm{N}$ fertilization rates under projected climate change scenarios from 2000 to 2100 at the district scale.

\begin{tabular}{|c|c|c|c|c|c|c|c|c|}
\hline \multirow[t]{2}{*}{ Crop } & \multirow[t]{2}{*}{ Climate change scenario } & \multirow[t]{2}{*}{ Nitrogen use rate } & 2000 & 2100 & Mean $^{\mathrm{a}}$ & Stdev & T Test & \multirow{2}{*}{$\begin{array}{r}\text { Change }^{\mathrm{b}} \\
(\%)\end{array}$} \\
\hline & & & \multicolumn{4}{|c|}{$\mathrm{MgCha}^{-1}$} & vs. N4 & \\
\hline \multirow[t]{9}{*}{ Maize } & \multirow[t]{3}{*}{$\mathrm{NCC}$} & N4 & 1.49 & 1.32 & 1.42 & 0.10 & & -11 \\
\hline & & N30 & 1.49 & 1.88 & 1.77 & $0.09^{* * *}$ & & 26 \\
\hline & & N60 & 1.49 & 2.17 & 2.04 & $0.14^{* * *}$ & & 46 \\
\hline & \multirow[t]{3}{*}{$\mathrm{LCC}$} & N4 & 1.49 & 1.30 & 1.40 & 0.05 & & -12 \\
\hline & & N30 & 1.49 & 1.79 & 1.69 & $0.14^{* * *}$ & & 20 \\
\hline & & N60 & 1.49 & 2.11 & 2.04 & $0.15^{* * *}$ & & 42 \\
\hline & \multirow[t]{3}{*}{$\mathrm{HCC}$} & N4 & 1.49 & 1.07 & 1.23 & 0.16 & & -28 \\
\hline & & N30 & 1.49 & 1.67 & 1.66 & $0.14^{* * *}$ & & 12 \\
\hline & & N60 & 1.49 & 1.90 & 1.99 & $0.14^{* * *}$ & & 27 \\
\hline \multirow[t]{9}{*}{ Cocoyam } & \multirow[t]{3}{*}{$\mathrm{NCC}$} & N4 & 8.48 & 8.94 & 8.58 & 0.39 & & 5 \\
\hline & & N30 & 8.48 & 11.23 & 10.97 & $0.55^{* * *}$ & & 33 \\
\hline & & N60 & 8.48 & 14.67 & 13.94 & $1.19^{* * *}$ & & 73 \\
\hline & \multirow[t]{3}{*}{ LCC } & N4 & 8.48 & 8.32 & 8.65 & 0.15 & & -2 \\
\hline & & N30 & 8.48 & 10.99 & 10.80 & $0.54^{* * *}$ & & 30 \\
\hline & & N60 & 8.48 & 14.52 & 13.83 & $1.24^{* * *}$ & & 71 \\
\hline & \multirow[t]{3}{*}{$\mathrm{HCC}$} & N4 & 8.48 & 7.58 & 8.36 & 0.38 & & -11 \\
\hline & & N30 & 8.48 & 10.50 & 10.68 & $0.50 * * *$ & & 24 \\
\hline & & N60 & 8.48 & 14.10 & 13.74 & $1.20^{* * *}$ & & 66 \\
\hline \multirow[t]{9}{*}{ Cassava } & \multirow[t]{3}{*}{$\mathrm{NCC}$} & N4 & 9.64 & 9.80 & 9.51 & 0.39 & & 2 \\
\hline & & N30 & 9.64 & 10.56 & 10.37 & $0.19^{* * *}$ & & 9 \\
\hline & & N60 & 9.64 & 12.49 & 12.10 & $0.61^{* * *}$ & & 29 \\
\hline & \multirow[t]{3}{*}{ LCC } & N4 & 9.64 & 9.64 & 9.75 & 0.06 & & 0 \\
\hline & & N30 & 9.64 & 10.35 & 10.29 & $0.17^{* * *}$ & & 7 \\
\hline & & N60 & 9.64 & 12.34 & 11.97 & $0.62^{* * *}$ & & 28 \\
\hline & \multirow[t]{3}{*}{$\mathrm{HCC}$} & N4 & 9.64 & 8.84 & 9.50 & 0.29 & & -8 \\
\hline & & N30 & 9.64 & 9.80 & 10.11 & $0.20^{* * *}$ & & 2 \\
\hline & & N60 & 9.64 & 11.89 & 11.84 & $0.55^{* * *}$ & & 23 \\
\hline
\end{tabular}

a Average grain yield for the 21 st century.

${ }^{b}$ Change percentage of grain yield by the year 2100 based on that in 2000 .

NCC, LCC, and HCC represent no, low, and high climate change scenarios, respectively.

$\mathrm{N} 4, \mathrm{~N} 30$, and $\mathrm{N} 60$ refer to nitrogen fertilization rates of 4,30 , and $60 \mathrm{~kg} \mathrm{~N} \mathrm{ha}^{-1}, \mathrm{yr}^{-1}$, respectively.

${ }^{*},{ }^{* *}$, and ${ }^{* * *}$ represent significant difference in means at $p<0.1,0.05$, and 0.01 , respectively.

The difference in mean yield between N30 and N60 were tested significant at $p<0.01$.

1991). Thus the nutritional demand of plants for $\mathrm{N}$ has to be met through decomposition of soil organic matter (or soil $\mathrm{N}$ mineralization) if no external $\mathrm{N}$ supply is available. It has become a common measure to increase crop production by applying $\mathrm{N}$ fertilizers even though fossil-fuel emissions and biomass burning have led to a significant addition of $\mathrm{N}$ to terrestrial ecosystems worldwide (Matson et al., 2002). And it has been also proven that an addition of $\mathrm{N}$ to most of cultivated lands is an important measure to sequester atmospheric C into soils (Christopher and Lal, 2007).

The ratio of $\mathrm{C}$ and $\mathrm{N}$ in a given soil is relatively stable. That means both $\mathrm{C}$ and $\mathrm{N}$ components in soil organic matter are proportionally coupled. Normally, cropland soil has higher $\mathrm{N}$ mineralization rate because of higher $\mathrm{N}$ requirements of crops (such as corn) in comparison with non- cultivated soils such as grassland (Schimel, 1986). Once fertilizer $\mathrm{N}$ is added to soils, especially to soils with low $\mathrm{N}$ availability, crops preferably use the fertilizer- $\mathrm{N}$ and do not necessarily take $\mathrm{N}$ from the decomposition of soil organic matter. On the other hand, increased $\mathrm{N}$ input enhances crop biomass formation of both above- and below-ground components, which is likely significant for soils with low soil $\mathrm{N}$ contents, because $\mathrm{N}$-limited systems initially retain anthropogenic $\mathrm{N}$ by using it for plant and microbial growth as well as accumulation in biomass and soil organic matter (Matson et al., 2002; Christopher and Lal, 2007). That is why our study shows that crop yields and SOC stocks tend to increase with increased $\mathrm{N}$ fertilization rates. Because our model simulation results came out with an assumption that each $\mathrm{N}$ fertilization rate scenario was set with no changes in all other 
Table 5. Responses of soil organic $\mathrm{C}$ budgets in all cropping systems to nitrogen fertilization rates and projected climate change scenarios during the 21 st century at the district scale.

\begin{tabular}{|c|c|c|c|c|c|c|c|}
\hline \multirow[t]{2}{*}{ Climate change scenario } & \multirow[t]{2}{*}{ Nitrogen use rate } & 2000 & 2100 & Mean $^{\mathrm{a}}$ & Stdev & \multirow{2}{*}{$\begin{array}{l}\text { T Test } \\
\text { vs. N4 }\end{array}$} & \multirow{2}{*}{$\begin{array}{r}\text { Change }^{b} \\
(\%)\end{array}$} \\
\hline & & \multicolumn{4}{|c|}{$\mathrm{MgCha}^{-1}$} & & \\
\hline \multirow[t]{3}{*}{$\mathrm{NCC}$} & N4 & 21.4 & 20.6 & 20.8 & 0.4 & & -4 \\
\hline & N30 & 21.4 & 24.1 & 24.5 & $0.7^{* * *}$ & & 12 \\
\hline & N60 & 21.4 & 28.0 & 27.6 & $1.5^{* * *}$ & & 31 \\
\hline \multirow[t]{3}{*}{ LCC } & $\mathrm{N} 4$ & 21.4 & 17.6 & 19.6 & 1.3 & & -18 \\
\hline & N30 & 21.4 & 20.9 & 21.9 & $0.5^{* * *}$ & & -2 \\
\hline & N60 & 21.4 & 25.1 & 25.3 & $1.1^{* * *}$ & & 17 \\
\hline \multirow[t]{3}{*}{$\mathrm{HCC}$} & N4 & 21.4 & 16.5 & 19.1 & 1.7 & & -23 \\
\hline & N30 & 21.4 & 20.0 & 21.6 & $0.8^{* * *}$ & & -7 \\
\hline & N60 & 21.4 & 24.6 & 24.9 & $0.9^{* * *}$ & & 15 \\
\hline
\end{tabular}

a Average soil organic carbon stock for the 21st century.

${ }^{b}$ Change percentage of soil organic carbon stock by the year 2100 based on that in 2000 .

NCC, LCC, and HCC represent no, low, and high climate change scenarios, respectively.

$\mathrm{N} 4, \mathrm{~N} 30$, and $\mathrm{N} 60$ refer to nitrogen fertilization rates of 4,30 , and $60 \mathrm{~kg} \mathrm{~N} \mathrm{ha}^{-1} \mathrm{yr}^{-1}$, respectively.

*** represents significant difference in means at $p<0.01$.

The difference in mean soil organic carbon stock between N30 and N60 were tested significant at $p<0.01$.

Table 6. Partial correlations of both SOC stock and crop yields to climate variables under low and high climate change scenarios projected for the 21 st century.

\begin{tabular}{lllll}
\hline Climate change scenario & Driving variable & \multicolumn{3}{c}{ Partial Correlation Coefficient } \\
& & Cultivated savanna & Woodlands & Crop Yield \\
\hline \multirow{2}{*}{ LCC } & Annual precipitation & $0.50^{* *}$ & $0.82^{* * *}$ & $-0.57^{* * *}$ \\
& Mean annual min temp & $0.35^{*}$ & $0.68^{* * *}$ & -0.16 \\
& Mean annual max temp & -0.07 & 0.22 & $-0.42^{* *}$ \\
Statistics & \% of variance explained & 98 & 96 & 44 \\
& F value & 338 & 198 & 4 \\
& Pr>F & $<0.0001$ & $<0.0001$ & $<0.0132$ \\
HCC & Annual precipitation & $0.35^{*}$ & $0.73^{* * *}$ & $-0.40^{*}$ \\
& Mean annual min temp & -0.25 & $0.42^{*}$ & -0.10 \\
& Mean annual max temp & 0.05 & -0.17 & -0.13 \\
Statistics & \% of variance explained & 99 & 98 & 55 \\
& F value & 593 & 336 & 6 \\
& Pr $>$ F & $<0.0001$ & $<0.0001$ & $<0.0015$ \\
\hline
\end{tabular}

LCC, low climate change scenario; HCC, high climate change scenario. ${ }^{*},{ }^{* *}$, and ${ }^{* * *}$ represent significant at $p<0.1,0.05$, and 0.01 level, respectively.

management practices, the responses of SOC stocks illustrated in Fig. 6 can be mainly attributed to the $\mathrm{N}$ fertilizerenhanced increment in biomass. This can be seen by comparing both Figs. 5 and 6 but the responses to $\mathrm{N}$ fertilization will become weaker with an accumulation of SOC and accompanying N. Those temporal trends may be significantly different if any changes in other management practices are simultaneously introduced. For example, retained residue can further aid the maintenance of SOC and SON in cropping systems as would fallow, mulching, manuring and other management systems (Tschakert, et al., 2004). 


\section{Sensitivity of SOC dynamics and crop yields to climate change scenarios}

We applied the univariate multiple regression model (SAS Institute, 2003) to identify the correlations of either the SOC budget or crop yield to climate variables. The statistics presented in Table 6 indicate that the SOC stock during the 21st century will significantly depend on the changes either in precipitation, temperature, or in both if there is no change in land use and management. The sensitivity, however, depends on the nature of ecosystem and climate change scenario. Generally, the variation in precipitation determines the SOC budgets in both natural and managed ecosystems. An increase in temperature tends to enhance SOC decomposition, especially in managed lands. On the other hand, crop yields show significantly differences in response to these climate variables. Crop yields rely less on climate variables than do SOC budgets, implying some more critical drivers behind, of which $\mathrm{N}$ supply rate should be one as indicated by the simulation results from $\mathrm{N}$ fertilization scenarios presented in Table 4 and Fig. 5. Meanwhile, progressive warming tends to jeopardize crop production, especially with low $\mathrm{N}$ fertilization rate (N4) under HCC scenario. However, this kind of impact can be significantly offset by increasing $\mathrm{N}$ application rate. The climate changes projected for the future may not necessarily have a severe impact or control on ecosystem $\mathrm{C}$ fluxes and crop production in this study area. Adaptation strategies for the climate changes examined in this study illustrate the great need to insure adequate fertilizer inputs to sustain soil $\mathrm{C}$ levels and crop yields. Higher temperatures would also require attention to more temperature tolerant crop species.

\section{Summary}

Within this study area, the natural forest has degraded to secondary forest, and the savannas and herb/bush savanna either have been transformed to open cultivated savanna or are degrading and at risk of desertification. The ecosystem $\mathrm{C}$ and SOC budgets are sensitive to climate change, whereas crop yields are more strongly influenced by $\mathrm{N}$ fertilization rate and less influenced by climate change, depending on the requirements of individual crop species. In general, our simulations suggest that low levels of $\mathrm{N}$ fertilizer input will not sustain yields and will result in further depletion of SOC throughout the 21 st century. Fertilization rates round $30 \mathrm{~kg} \mathrm{~N} \mathrm{ha}^{-1} \mathrm{yr}^{-1}$ help sustain and improve crop production even though the SOC stock in cropping systems still tends to decrease. The rate of $60 \mathrm{~kg} \mathrm{~N} \mathrm{ha}^{-1} \mathrm{yr}^{-1}$, in contrast, will result in substantial $\mathrm{C}$ sequestration in the soil even under HCC scenario. Interestingly, the $\mathrm{N}$ fertilizer application at both moderate and high rates shows an early stimulation of $\mathrm{C}$ accretion even though this effect will deteriorate after 2040 under HCC and after 2060 even under LCC. These decreases may reflect the progressive warming and decreasing precipitation as the century proceeds, suggesting that adaptive management strategies need to be developed to sustain food security. This is similar but not as dramatic as the crop failures simulated for south-central Senegal. In sum, we draw the conclusions as follows:

(1) Deforestation for crop production has resulted in a substantial reduction in both ecosystem C and SOC stocks across the Ejura-Sekyedumasi district of Ghana during the 20th century.

(2) The adverse impacts of climate change on the SOC stock in croplands could be offset to some extent by $\mathrm{N}$ fertilization at $30 \mathrm{~kg} \mathrm{Nha}^{-1} \mathrm{yr}^{-1}$ or higher rates.

(3) Low $\mathrm{N}$ fertilization rate has been the principal constraint on current crop production, and to increase $\mathrm{N}$ fertilization would be a critical adaptive management measure to achieve food security and agricultural sustainability in the 21 st century.

(4) Adaptation strategies for climate change in this study area require national plans to support policies and practices that provide adequate $\mathrm{N}$ fertilizers to support soil $\mathrm{C}$ and crop yields and to consider high temperature tolerant crop species if these temperature projections are exceeded.

Acknowledgements. This is a contribution of SEMSOC (AEGP00 030001300), funded by the US Agency for International Development (USAID)/Climate Change program, Bureaus for Economic Growth, Agriculture, and Trade (EGAT) and Africa Bureau. Research was integrated with the Geographic Analysis and Monitoring (GAM) and the Earth Surface Dynamics programs of the USGS. The authors thank Zhengpeng Li for assistance in model implementation. Zhengxi Tan was supported under USGS contract 03CRCN0001.

Edited by: A. Arneth

\section{References}

Adiku, S. G. K., Rose, C. W., Gabric, A., Braddock, R. D., Carberry, P. S., and McCown, R. L.: An evaluation of performance of maize and cowpea in sole and intercropping systems at two savanna zones of Ghana: A simulation study, ISHS Acta Horticulturae 476, International Symposium on Applications of Modelling as Innovative Technique in the Agri-Food Chain, MODELIT, 1998.

Allotey, A. N. and Tachie-Obeng, E.: Agro-Ecological and LandCover Trends in Ghana, AGRHYMET Regional Centre, Niamey Niger, Unpublished Project Report, 2006.

Aweto, A. O.: Effects of shifting cultivation on a tropical rain forest soil in southwestern Nigeria, Turriaba, 38, 19-22, 1988.

Aweto, A. O. and Obe, O. A.: Comparative effects of a tree crop (cocoa) and shifting cultivation on a forest soil in Nigeria, Environmentalist, 13, 183-187, 1993. 
Christopher, S. F. and Lal, R.: Nitrogen management affects carbon sequestration in North American cropland soils, Critical Reviews in Plant Sciences, 26, 45-64, doi:10.1080/07352680601174830, 2007.

EarthTrends: Agriculture and food-Ghana, EarthTrends Country Profile, available at: http://earthtrends.wri.org/, 2003.

Ghana Environmental Protection Agency (EPA): Ghana's Initial National Communication, under the United Nations Framework Convention on Climate Change, EPA, Ghana, 160 pp., 2000.

Freitag, H., Ferguson, P. R., Dubois, K., Hayford, E. K., von Vordzogbe, V., and Veizer, J.: Water and carbon fluxes from savanna ecosystems of the Volta River watershed, West Africa, Global Planet. Change, 61, 3-14, doi:10.1016/j.gloplacha.2007.08.003, 2008

Guo, L. B. and Gifford, R. M.: Soil carbon stocks and land use change: a meta analysis, Glob. Change Biol., 8, 345-360, 2002.

Houghton, R. A.: Changes in the storage of terrestrial carbon since 1850, in: Soil and Global Change, edited by: Lal et al., CRC Lewis Publishers, Boca Raton, Florida, USA, 45-65, 1995.

Houghton, R. A.: Revised estimates of the annual net flux of carbon to the atmosphere from changes in land use and land management 1850-2000, Tellus B, 55, 378-390, 2003.

Houghton, R. A. and Hackler, J. L.: Carbon flux to the atmosphere from land-use changes: 1850 to 1990 , Rep. ORNL/CDIAC-131 NDP-050/R1, US Dept.of Energy, Oak Ridge Natl. Lab., Oak Ridge, Tennessee, 2001.

Houghton, R. A. and Hackler, J. L.: Emissions of carbon from land use change in sub-Saharan Africa, J. Geophys Res., 111, G02003, doi:10.1029/2005JG000076, 2006.

Hulme, M., Doherty, R., Ngara, T., New, M., and Lister, D.: African climate change: 1900-2100, Climate Res., 17, 145-168, 2001.

Johnson, D. W., Shan, J., Morris, L. A., et al.: Effects of forest management on soil carbon: results of some long-term resampling studies, Environ. Pollut., 116, S201-208, 2002.

Kelly, V. A.: Factors Affecting Demand for Fertilizer in SubSaharan Africa, Agriculture and Rural Development, World Bank, Discussion Paper 23, available at: http://www.worldbank. org/rural, 2006.

Kroeze, C., Mosier, A., and Bouwman, L.: Closing the global $\mathrm{N}_{2} \mathrm{O}$ budget: a retrospective analysis $1500-1994$, Global Biogeochem. Cycles, 13, 1-8, 1999.

Lal, R.: Tragedy of the Global Commons: Soil, Water, and Air, CSA News, 52, 10-11, 2007.

Liu, S., Kairé, M., Wood, E., Dialloc, O., and Tieszen, L. L.: Impacts of land use and climate change on carbon dynamics in south-central Senegal, J. Arid Environ., 59, 583-604, 2004a.

Liu, S., Loveland, T. R., and Kurtz, R. M.: Contemporary carbon dynamics in terrestrial ecosystems in the Southeastern Plains of the United States, Environ. Manage., 33, S442-S456, 2004b.

Matson, P., Lohse, K. A., and Hall, S. J.: The globalization of nitrogen deposition: consequences for terrestrial ecosystems, AMBIO: A Journal of the Human Environment, 31, 113-119, 2002.
Nemani, R. R., Keeling, C. D., Hashimoto, H., et al.: Climatedriven increases in global terrestrial net primary production from 1982 to 1999, Science, 300, 1560-1563, 2003.

Onumah, G. and Coulter, J.: A review of the maize commodity system in Ghana, Discussion Paper, NRI, Chatham, UK, 1-22, 2000.

Parton, W. J., Ojima, D. S., and Schimel, D. S.: Environmental change in grasslands: assessment using models, Climate Change, 28, 111-141, 1994.

Paul, E. A., Paustian, K., Elliot, E. T., and Cole, C. V.: Soil Organic Matter in Temperate Agroecosystems: Long-Term Experiments in North America, CRC Press, Inc., Boca Raton, Florida, 414 pp., 1997.

Reich, P. B., Hobbie, S. E., Lee, T., et al.: Nitrogen limitation c onstrains sustainability of ecosystem response to $\mathrm{CO}_{2}$, Nature, 440, 922-925, doi:10.1038/nature04486, 2006.

Reiners, W. A., Liu, S., Gerow, K. G., Keller, M., and Schimel, D. S.: Historical and future land use effects on trace gas emissions using an ensemble modeling approach: Costa Rica's Caribbean Lowlands as an example, Global Biogeochem. Cy., 16, 1068, doi:10.1029/2001GB001437, 2002.

Sankaran, M., Hanan, N. P., Scholes, R. J., et al.: Determinants of woody cover in African savannas, Nature, 438, 846-849, 2005.

SAS Institute: SAS User's Guide, Release 9.1, SAS Institute, Inc., Cary, NC, 2003.

Schimel, D. S.: Carbon and nitrogen turnover in adjacent grassland and cropland ecosystems, Biogeochemistry, 2, 345-357, 10.1007/BF02180325, 1986

Stephens, B. B., Gurney, K. R., Tans, P. P., et al.: Weak northern and strong tropical land carbon uptake from vertical profiles of atmospheric $\mathrm{CO}_{2}$, Science, 316(5832), 1732-1735, doi:10.1126/science.1137004, 2007.

Tan, Z., Liu, S., Johnston, C. A., Liu, J., and Tieszen, L. L.: Analysis of ecosystem controls on soil carbon source-sink relationships in the northwest Great Plains, Global Biogeochem. Cycles, 20, GB4012, doi:10.1029/2005GB002610, 2006a.

Tan, Z., Lal, R., and Liu, S.: Using experimental and geospatial data to estimate regional carbon sequestration potential under no-till practice, Soil Science, 171, 950-959, 2006b.

Tschakert, P., Khouma, M., and Sene, M.: Biophysical potential for soil carbon sequestration in agricultural systems of the Old Peanut Basin of Senegal, J. Arid Environ., 59, 511-534, 2004.

Vitousek, P. M. and Howarth, R.: Nitrogen limitation on land and in the sea: How can it occur?, Biogeochemistry, 13, 87-115, 1991.

Wigley, T. M. L., Raper, S. C. B., Salmon, M., and Hulme, M.: MAGICC: Model for the Assessment of Greenhouse-gas Induced Climate Change: Version 2.4, Climatic Research Unit, Norwich, UK, 2000.

Williams, C. A., Hanan, N. P., Neff, J. C., et al.: Africa and the global carbon cycle, Carbon Balance and Management, 2, 1-13, doi:10.1186/1750-0680-2-3, 2007. 